\title{
Glasgow Coma Scale
}

1. De auteurs beschrijven dat de Glasgow Coma Scale (GCS) in 1974 is ontwikkeld. Voor welk doel werd de GCS ontwikkeld en gevalideerd?

a. Het beoordelen van het bewustzijn van de acute patiënt.

b. Inschatten van de ernst van het hersenletsel.

c. Inschatten van de prognose van hersenletsel door herhaaldelijk bepalen van de score.

2. De GCS heeft al jaren een vaste plek binnen de acute geneeskunde. Wat wordt door de auteurs genoemd als nadeel van de GCS voor gebruik binnen de eerste lijn?

a. De schaal is complex en wordt niet altijd correct toegepast.

b. Het toepassen van de GCS kost (te) veel kostbare tijd tijdens de primary survey.

3. Welke fout wordt volgens Laven door onervaren hulpverleners het vaakst gemaakt in het scoren van de GCS?
a. Ze scoren te hoog.
b. Ze scoren te laag.

4. Bij welke score van de GCS is er sprake van coma?
a. 10 of lager
b. 8 of lager
c. 6 of lager

5. Voor welke score staat de letter $P$ in de AVPU-score?
a. Pain
b. Pallor
c. Problem

6. Bij welke score(s) van AVPU kun je spreken van een (relatief) veilige situatie?

a. Alleen bij A
b. Bij A en V
c. Bij A, V en P

7. De huisarts komt tijdens de avonddienst bij de heer Vertonghen, 86 jaar, die uit bed is gevallen. $\mathrm{Na}$ beoordeling van $\mathrm{ABC}$ wil de huisarts het bewustzijn bepalen middels de EMV-score. De heer Vertonghen voert geen opdracht uit. Bij toedienen van een pijnprikkel op de orbitarand brengt de heer Vertonghen zijn hand naar zijn oog. Welke score voor motorische reactie ('M') mag de huisarts hier noteren?
a. M5
b. M4
c. M3
d. M2

8. De huisarts is op visite bij mevrouw Surendonk, 78 jaar, die volgens haar dochter wat verward zou zijn. Bij aankomst zit mevrouw Surendonk in haar stoel en ze groet de huisarts. Zij neemt soms deel aan het gesprek, en lijkt soms wat af te dwalen. Haar antwoorden zijn niet altijd adequaat. Ze suft niet weg. Wat is op dit moment een correcte inschatting van de AVPU-score?
a. A
b. V
c. $\mathrm{P}$
d. U

9. Mevrouw Gaastra, 23 jaar, wordt door haar vriendinnen naar de huisartsenpost gebracht. Tijdens het uitgaan is ze onwel geworden. Terwijl ze wachten in de wachtkamer raakt mevrouw Gaastra buiten bewustzijn. De huisarts beoordeelt haar met spoed en vindt geen afwijkingen in $\mathrm{ABC}$. Om een inschatting te maken

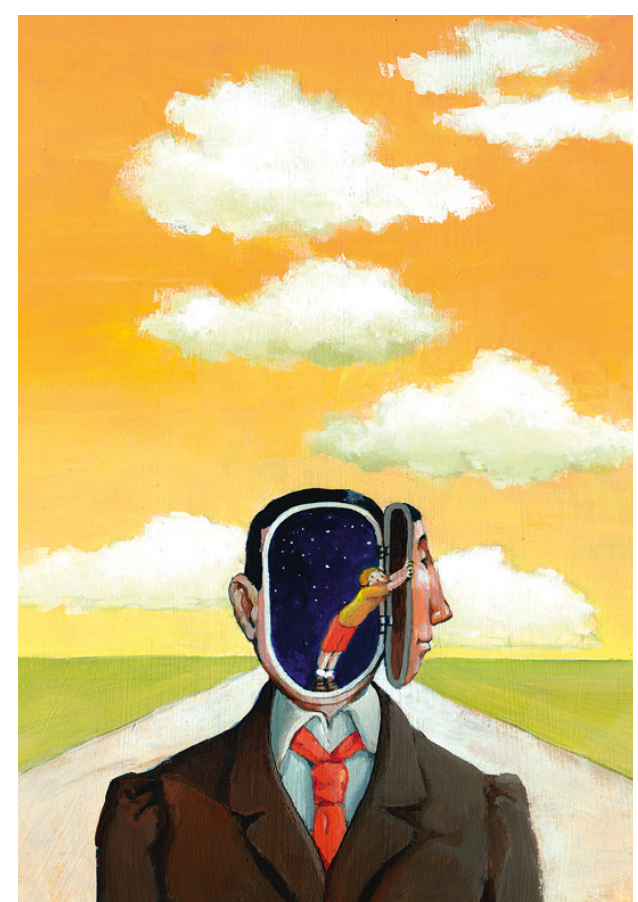

Foto: Shutterstock

van het bewustzijn dient de huisarts een pijnprikkel toe, waarop mevrouw Gaastra verbaal agressief reageert. Wat is de juiste inschatting van het bewustzijn op dit moment?
a. A
b. V
c. $\mathrm{P}$
d. U

De kennistoets is gemaakt door Anne Klijnsma, werkzaam bij Huisartsopleiding Nederland. Over vragen en antwoorden wordt niet gecorrespondeerd.

\section{GEBRUIKTE BRONNEN}

Laven R. Een alternatief voor de Glasgow Coma Scale. Huisarts Wet 2018;61[10]:34-6.

NHG. ABCDE-kaart voor huisartsen. https://www. nhg.org/sites/default/files/content/nhg_org/ uploads/abcde-kaart_a6_definitief.pdf.

\section{ANTWOORDEN}

ग6/ q8 / e L / q9 / es / qh / qE / e己 / ग 